J. Lake Sci. (湖泊科学), 2018, 30(6): 1707-1721

DOI 10. 18307/2018. 0622

(C) 2018 by Journal of Lake Sciences

\title{
新疆艾比湖主要入湖河流同位素及水化学特征的季节变化”
}

\author{
朱世 ${ }^{1,2}$, 张 $^{1,2,3 * *}$, 张海威 $^{1,2}$, 张贤龙 $^{1,2}$ \\ ( 1 : 新疆大学资源与环境科学学院智慧城市与环境建模普通高校重点实验室, 乌鲁木齐 830046) \\ ( 2 : 新疆大学绿洲生态教育部重点实验室, 乌鲁木齐 830046) \\ (3: 中亚地理信息开发利用国家测绘地理信息局工程技术研究中心,乌鲁木齐 830002)
}

\begin{abstract}
摘 要: 通过野外调查取样和室内测试分析, 利用水文化学以及氢氧稳定同位素技术, 分析艾比湖主要人湖河流氢氧同 位素及水化学的组成特征, 并探讨其季节性变化. 结果表明: 地表水水质指标高值多出现于博乐市、温泉市和精河县及艾 比湖湿地附近, 主要污染为水体富营养化、工矿业污染以及有机质污染, 其污染程度夏、秋季高于春、冬季. 河水的 $\delta^{18} \mathrm{O}$ 与 $\delta^{2} \mathrm{H}$ 存在明显的线性关系, 其相关指数为夏季 $\left(R^{2}=0.99\right)>$ 春季 $\left(R^{2}=0.98\right)>$ 秋季 $\left(R^{2}=0.96\right)>$ 冬季 $\left(R^{2}=0.90\right)$, 均沿当地 大气降水线分布, 受西北干早区强烈的蒸发作用影响, 各季节河流斜率均小于 8 , 氞过量参数值多为正值. 博尔塔拉河与 精河地表水体 $\delta^{18} \mathrm{O}$ 值整体上表现为沿流程逐渐偏正的趋势, 博尔塔拉河水体氢氧同位素与高程相关指数表现为春季 $\left(R^{2}=0.70\right)>$ 冬季 $\left(R^{2}=0.57\right)>$ 夏季 $\left(R^{2}=0.45\right)>$ 秋季 $\left(R^{2}=0.30\right)$, 精河因其海拔差异不大, 流程简短, 与高程相关性低. 博 尔塔拉河和精河氢氧同位素与氯化物、硫酸盐、五日生物需氧量等指标间存在相关性, 且在夏、秋季最大, 相关系数 $R>$ 0.75, 与总磷、 $\mathrm{Cu}^{2+}$ 、色度、浊度等指标基本都不显著相关,相关系数 $R<0.25$.
\end{abstract}

关键词: 人湖河流;水质指标;稳定同位素;季节变化;艾比湖;精河;博尔塔拉河

\section{Seasonal variation of the isotope and hydrochemical characteristics of the main lake rivers in Lake Ebinur, Xinjiang}

\author{
ZHU Shidan ${ }^{1,2}$, ZHANG Fei ${ }^{1,2,3 * *}$, ZHANG Haiwei ${ }^{1,2}$ \& ZHANG Xianlong ${ }^{1,2}$ \\ (1: Key Laboratory of Wisdom City and Environment Modeling of Resources and Environmental Science College, Urumqi \\ 830046, P.R.China) \\ (2: Key Laboratory of Oasis Ecology, Xinjiang University, Urumqi 830046, P.R. China) \\ ( 3: Engineering Research Center of Central Asia Geoinformation Development and Utilization, National Administration of Sur- \\ veying, Mapping and Geoinformation, Urumqi 830002, P.R.China)
}

Abstract: The important exposition of 'green mountains and clear water are as good as mountains of gold and silver' shows that Chinese leaders attach importance to ecological environment construction. The study on the healthy and sustainable development of lakes in the arid region of Northwest China, where is short of water resource and is of a fragile ecological environment. It is an indispensable part of constructing the harmonious development of economy and environment in China. As a typical closed lake in arid area of Xinjiang, Lake Ebinur is the lowest discharge datum in this area. The unique water cycle makes it highly sensitive to climate change and human activity. In recent years, with the further large-scale exploitation of water and soil resources in the Lake Ebinur wetland and the abundant supply rivers, the ecosystem of the Jinghe River Basin has been seriously disturbed, for example, the desertification and salinization are obviously intensified, and the ecological environment is deteriorating day by day. Therefore, maintaining the water quality of the river into the lake has become an important means to maintain the water balance and the ecological environment of the Lake Ebinur. This paper made an in-depth study of mainly rivers in the Lake Ebinur Basin on October 2016, March 2017, May and July. The characteristics of hydrochemistry and hydrogen and oxygen isotopes are systematically studied. The results show that most high value of water quality indicators appeared in Bole, Wenquan, Jinghe County and near the Lake Ebinur.

* 国家自然科学基金项目 (41361045) 和新疆本地优秀青年培养专项 ( U1503302) 联合资助. 2018-01-30 收稿; 2018-03-27 收修改稿. 朱世丹(1995 ), 女, 硕士研究生; E-mail : 15276606619@163.com.

** 通信作者;E-mail: zhangfei3s@163.com. 
The main pollution is from water eutrophication, industrial and mining industry and organic matter. The pollution degree in summer and autumn is higher than that in spring and winter. There is obvious linear relationship between $\delta^{18} \mathrm{O}$ and $\delta^{2} \mathrm{H}$, and its coefficient was as follows: summer $\left(R^{2}=0.99\right)>$ spring $\left(R^{2}=0.98\right)>$ autumn $\left(R^{2}=0.96\right)>$ winter $\left(R^{2}=0.90\right)$. The distribution of water line along the local atmosphere. Influenced by the strong evaporation of the northwest arid region, the slope of the rivers in each season is less than 8 , and the $d$-excess value is positive. The value of $\delta^{18} \mathrm{O}$ in Bortala and Jinghe River shows a trend of gradual deviation along the flow. The index of correlation between hydrogen and oxygen isotopes in Bortala River and height is that spring $\left(R^{2}=\right.$ $0.70)>$ winter $\left(R^{2}=0.57\right)>$ summer $\left(R^{2}=0.45\right)>$ autumn $\left(R^{2}=0.30\right)$. The correlation between $\delta^{18} O$ and elevation in Jinghe River is low due to the small difference in altitude and short process. The hydrogen and oxygen isotopes of Bortala River and Jinghe River were correlated with chloride, $\mathrm{BOD}_{5}$ and so on. The correlation coefficients $(R)$ was higher than 0.75 in summer and autumn.

Keywords: Rivers into the lake; water quality indicator; stable isotope; seasonal variation; Lake Ebinur; Jinghe River; Bortala River

水资源供需矛盾随全球气候变暖及现代化进程的加快日益加剧, 湖泊水资源短缺和水环境污染等问题 受到越来越多国家的关注. 作为水分子直接组成部分的氢氧同位素, 其在流域研究中的应用有着悠久的历

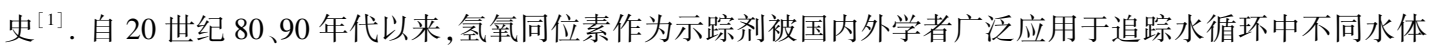
的补给来源、探讨不同水体间的转化关系、估算河流和湖泊的水体蒸发等 ${ }^{[2-8]}$, 以此指示水循环过程中的环 境变化. 目前已研究的有关世界主要大江大河包括欧洲的莱茵河和多瑙河、印度的恒河、南美的亚马逊河、 韩国的汉江以及中国的长江和黄河等 ${ }^{[9-14]}$. 受土地类型、气候及人为活动的影响, 河流水体中氢氧同位素组 成的时空变化和空间分布是对降水、冰雪融水、地下水等补给源中的氢氧同位素特征以及河流受蒸发作用 影响的综合响应 ${ }^{[15]}$. 结合前人研究, 可知河流氢氧同位素的主要影响因素为不同补水源 (降水、冰川融水、 地下水) 的影响. 大气降水的同位素组成与温度、纬度、季节、高程和降水量效应存在直接关系, 如降水氢氧 同位素随纬度的升高、温度的降低逐渐贫化 ${ }^{[16]}$. 而由于冰雪中 $\delta^{18} \mathrm{O}$ 较贫化, 地下水受到的蒸发作用较小以 及其与围岩和气体同位素的交换,一般冰川融水及地下水补给的河流 $\delta^{18} 0$ 较贫化 ${ }^{[9,17]}$. 人类活动的影响, 主 要表现为大规模开垦耕地、修建水电站和工业用水致使径流量减少, 从而影响水体氢氧同位素富集程 度 ${ }^{[18-19]}$. 此外,多元统计法作为分析水质基本特征、评价水体健康、探讨水体污染源最为基础的一种方法被 国内外许多专家用于评价水环境健康 ${ }^{[20-22]}$. 近年来, 许多学者结合氢氧同位素和水化学特征对流域水资源 问题进行更深度的分析研究, 如对冰川河流在气候变化下的敏感度研究 ${ }^{[23]}$, 水化学类型和同位素的形成原 因及环境意义 ${ }^{[24]}$, 稳定同位素在水循环各环节中的分馈规律 ${ }^{[25]}$ 等, 为相关部门水资源治理提供科学依据.

“金山银山, 不如绿水青山” 的重要论述展示中国领导人对生态环境建设的重视. 对水资源匮乏、生态环 境脆弱的西北干旱区湖泊的健康和可持续发展的研究是我国建设经济一环境和谐发展必不可少的一部分. 艾比湖作为新疆干旱区典型封闭型湖泊, 为该地区最低排泄基准面, 接受降水、地表径流和地下径流补给, 无出湖径流, 蒸发是其唯一的排泄方式 ${ }^{[26]}$. 独特的水循环系统使其对气候变化和人类活动影响具有高度敏 感性 ${ }^{[27]}$. 近年来, 随着艾比湖湿地进一步大规模的水土资源开发, 补给河流博、精河流域生态系统受到严重 干扰, 荒漠化和盐碱化明显加剧, 生态环境日益恶化, 严重影响了湖泊生态功能 ${ }^{[28]}$. 因此, 维护入湖河流水 质健康成为维持艾比湖水量平衡和生态环境健康的重要手段. 前人对艾比湖流域的研究主要集中在流域水 质分异特征及污染源解析 ${ }^{[22]}$ 、流域生态服务价值 ${ }^{[29]}$ 等方面, 尚未有关于艾比湖流域氢氧同位素组成及其变 化特征的深人研究. 因此本文于 2016 年 10 月以及 2017 年 3 月、 5 月和 7 月对艾比湖主要人湖河流进行系 统采样分析, 并进行季节性的水化学特征与氢氧同位素特征的系统性研究, 以期为更深人认识艾比湖流域 的水文过程及沿程人类活动对河水的影响提供科学依据.

\section{1 材料与方法}

\section{1 研究区概况}

艾比湖区 $\left(44^{\circ} 05^{\prime} \sim 45^{\circ} 08^{\prime} \mathrm{N}, 82^{\circ} 35^{\prime} \sim 83^{\circ} 16^{\prime} \mathrm{E}\right)$ 是喜马拉雅造山运动形成的断陷盆地, 位于新疆准噶尔 盆地西部, 湖盆为最低洼地, 海拔在 $190 \mathrm{~m}$ 左右, 湖面面积为 $490 \mathrm{~km}^{2}$, 平均深度为 $2.2 \mathrm{~m}$, 是新疆第一大盐湖. 
流域内年平均气温为 $7.36^{\circ} \mathrm{C}$, 多年平均降雨量为 $100 \sim 200 \mathrm{~mm}$, 多年平均蒸发量为 $1500 \sim 2000 \mathrm{~mm}$, 属典型的 温带大陆性气候 ${ }^{[30]}$. 由于其南、西、北三面环山, 东部与古尔班通古特沙漠相连, 西北的冷空气难以长驱直 人, 该地具有 “热量丰富、日照充足、干旱少雨、蒸发强烈” 的特点 ${ }^{[31]}$. 按气象可将艾比湖流域季节划分为: 春 季( $3-5$ 月)、夏季 $\left(6-8\right.$ 月)、秋季 $(9-11 \text { 月)、冬季 ( } 12 \text { 月一次年 } 2 \text { 月 })^{[32]}$, 故本文将 5 月定为春季, 7 月定 为夏季, 10 月定为秋季, 按气象划分可知连续 5 天气温小于 $10^{\circ} \mathrm{C}$ 为冬季, 而 2017 年 3 月平均最高温度为 $2.32^{\circ} \mathrm{C}$, 故本文将 3 月定为冬季. 又因每年 3-6 月最后一次连续 5 天日均温度低于零度的日期定义为融雪 期开始时间 ${ }^{[33]}$, 研究区 2017 年融雪期开始于 3 月 21 日,而水样采于 3 月 24-30 日, 加之流域日夜温差大, 故采集水样时河流无结冰. 艾比湖湖水补给主要来源于降雨、地表径流及地下水,其中以地表径流补给湖泊 的河流主要有 3 条, 即奎屯河、博尔塔拉河和精河. 但在气候变化和人为活动的影响下, 人湖河流径流量逐 年减少,其中水量最大、流程最长的奎屯河于 $1970 \mathrm{~s}$ 中期全部被拦截而完全断流, 现仅剩博尔塔拉河 (后均 以“博河”代替) 和精河两条补给河流 ${ }^{[34]}$. 博河和精河流域径流均以冰雪水、降雨、地下水混合补给, 根据博 尔塔拉政府网 (http://www.xjboz.gov.cn) 公布的 2016 年博州水资源公报可知, 博河和精河多年平均径流量 分别为 4.9 亿和 4.7 亿 $\mathrm{m}^{3}$, 多年平均降雨量分别约为 207.7 和 $151.5 \mathrm{~mm}, 2016$ 年年均地下水量分别为 4.75 亿和 5.94 亿 $\mathrm{m}^{3}$. 博河与精河河流源区冰川融水比重分别占其各自河流水量的 $22.2 \%$ 和 $20.4 \%{ }^{[35-36]}$. 因此, 本文选择精河和博河作为研究对象,对其稳定氢氧同位素及水化学特征的季节变化进行分析.

\section{2 样品采集及处理}

本研究分别于 2016 年 10 月以及 2017 年 3 月、 5 月和 7 月对艾比湖主要人湖河流——精河和博河进行 样品采集, 共 37 个采样点, 其中博河 23 个,精河 14 个, 取样点位置多位于干流 (图 1). 样品采集使用 $1 \mathrm{~L}$ 聚 乙烯瓶, 采样前用去离子水清洗、晾干后密封待用, 从河流中间取水, 沿博河上游每隔 $2 \mathrm{~km}$ 采集 1 个水样, 精 河从上游的下天吉水库往下每隔 $2 \mathrm{~km}$ 采集 1 个水样, 并用 GPS 实时记录采样点的经纬度坐标 ${ }^{[37]}$. 利用水 质监测仪 (YSI 600) 样品采集时, 贴好标签, 于 $<4^{\circ} \mathrm{C}$ 冷藏箱内密封保存, 并尽快带回实验室测定分析. 在采集 水样后 $24 \mathrm{~h}$ 内, 送至乌鲁木齐京诚检测技术有限公司, 选取悬浮物 (SS)、化学需氧量 (COD)、五日生化需氧 量 $\left(\mathrm{BOD}_{5}\right)$ 、总氮 $(\mathrm{TN}) 、$ 总磷 $(\mathrm{TP}) 、$ 、浊度 (Turbidity)、色度 (Chromaticity)、矿化度 (Mineralization degree)、氨氮 $\left(\mathrm{NH}_{3}-\mathrm{N}\right)$ 、挥发酚 (Volatile phenol)、氯化物 (Chloride)、硫酸盐 (Sulphate)、三价铁离子 $\left(\mathrm{Fe}^{3+}\right)$ 、锌离子 $\left(\mathrm{Zn}^{2+}\right)$ 、钴离子 $\left(\mathrm{Co}^{2+}\right)$ 、铜离子 $\left(\mathrm{Cu}^{2+}\right)$ 和镁离子 $\left(\mathrm{Mg}^{2+}\right)$ 共 17 项指标严格按照《地表水环境质量标准》(GB $3838-2002)$ 中的方法进行分析, 详细实验方法见表 1 .

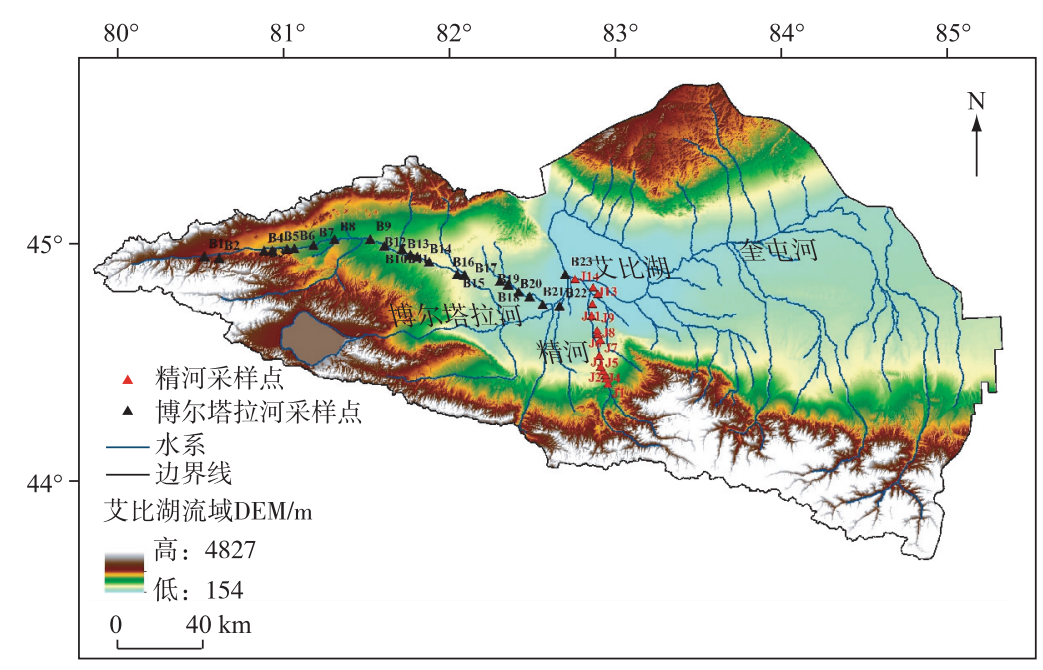

图 1 研究区示意图

Fig.1 The schematic diagram of the study area

在采集水样后 $24 \mathrm{~h}$ 内, 将用于稳定氢氧同位素分析的样品过滤后装于 $5 \mathrm{ml}$ 玻璃瓶中, 并用 PARAFILM 
密封, 送于中国科学院新疆生态与地理研究所测试, $\delta^{18} \mathrm{O}$ 和 $\delta^{2} H$ 的测定精度分别为 $\pm 0.1 \% 0$ 和 $\pm 0.8 \%$, 其测定 结果以相对维也纳海水 (Vienna Standard Mean Ocean Water, VSMOW) 的千分偏差表示 ${ }^{[38]}$.

$$
\delta=\frac{R_{\text {Sample }}-R_{\text {VSMow }}}{R_{\text {VSMow }}} \times 1000 \%
$$

表 1 水质指标及实验方法

Tab.1 Water indexes and experiment methods

\begin{tabular}{|c|c|c|c|}
\hline 水体指标 & 实验方法 & 仪器 & 检出限 \\
\hline SS & 重量法( GB 11901－1989) & 万分之一天平 SI-234 & $4 \mathrm{mg} / \mathrm{L}$ \\
\hline COD & 重铬酸盐法( GB 11914－1989) & 标准 COD 消解器( KY-100) & $5 \mathrm{mg} / \mathrm{L}$ \\
\hline $\mathrm{BOD}_{5}$ & 稀释与接种法 ( HJ 505－2009) & 恒温培养箱( HWS-150 型) & $0.5 \mathrm{mg} / \mathrm{L}$ \\
\hline $\mathrm{TN}$ & 紫外分光光度法 ( HJ 636-2012) & 紫外可见分光光度计( UV-6100) & $0.05 \mathrm{mg} / \mathrm{L}$ \\
\hline $\mathrm{TP}$ & 钿酸铵分光光度法 (HJ 11893-1989) & 可见分光光度计(722N) & $0.01 \mathrm{mg} / \mathrm{L}$ \\
\hline 浊度 & 分光光度法(GB 13200－1991) & 可见分光光度计 (722N) & $1 \mathrm{NTU}$ \\
\hline 色度 & 铂钴比色法(GB 11903－1989) & - & 5 度 \\
\hline 矿化度 & 残渣烘干－质量法 (SL-79－1994) & - & - \\
\hline 氨氮 & 纳氏试剂分光光度法( HJ 535-2009) & 可见分光光度计(722N) & $0.025 \mathrm{mg} / \mathrm{L}$ \\
\hline 挥发酚 & 蒸馏后 4-氨基安替比林分光光度法( GB 7490-1987) & 可见分光光度计(722N) & $0.002 \mathrm{mg} / \mathrm{L}$ \\
\hline 氯化物 $\left(\mathrm{Cl}^{-}\right)$ & 硝酸银滴定法( GN T 11896) & - & $0.007 \mathrm{mg} / \mathrm{L}$ \\
\hline 硫酸盐( $\mathrm{SO}_{4}^{2-}$ ) & EDTA 间接络合滴定法 & - & $0.018 \mathrm{mg} / \mathrm{L}$ \\
\hline 三价铁离子 $\left(\mathrm{Fe}^{3+}\right)$ & 火焰原子吸收分光光度法( GB 11905－1989) & 原子吸收分光光度计 & $0.03 \mathrm{mg} / \mathrm{L}$ \\
\hline 锌离子 $\left(\mathrm{Zn}^{2+}\right)$ & 原子吸收分光光度法 ( GB 7475-1987) & 原子吸收分光光度计 & $0.05 \mathrm{mg} / \mathrm{L}$ \\
\hline 钴离子 $\left(\mathrm{Co}^{2+}\right)$ & PADAP 法 & 水质分析仪 GDYS-201 M & $0.01 \mathrm{mg} / \mathrm{L}$ \\
\hline 铜离子 $\left(\mathrm{Cu}^{2+}\right)$ & 原子吸收分光光度法鳌合萃取法( GB 7475－1987) & 原子吸收分光光度计 & $0.001 \mathrm{mg} / \mathrm{L}$ \\
\hline 镁离子 $\left(\mathrm{Mg}^{2+}\right)$ & EDTA 间接络合滴定法 & - & $0.002 \mathrm{mg} / \mathrm{L}$ \\
\hline
\end{tabular}

\section{3 研究分析}

通过分析数据和绘制各水质指标和氢氧同位素的时空序列变化趋势图, 研究各水质指标和氢氧同位素 的基本特征和时空变化特征. 利用因子分析法进一步分析不同季节博河、精河地表水水质主要污染的可能 来源, 并通过绘制氢氧同位素不同季节的关系图、気过量参数 ( $d$-excess 值) 分布图以及 $\delta^{18} 0$ 与高程的线性 相关图, 研究地表水中氢氧同位素潜在机制. 最后, 通过相关分析法确定不同季节地表水各水质指标与氢氧 同位素之间的相关性,初步分析氢氧同位素与不同季节同水质指标间的联系.

\section{2 结果与讨论}

\section{1 主要入湖河流地表水水化学组成}

2.1.1 入湖河流水体水质指标不同季节的沿程变化 博河与精河不同季节的各水质指标中均有异常高值存 在, 高值多分布于精河人湖口、精河与博河交汇处、博河下游及博乐市、温泉市和精河县附近 (图 2、3). 除 $\mathrm{NH}_{3}-\mathrm{N} 、 \mathrm{Cl}^{-} 、 \mathrm{SO}_{4}^{2-}$ 浓度沿博河、精河上游至下游呈现较为明显的上升趋势, 且冬季较高, 其余指标无明显的变 化规律. 由于近年来经济发展迅速, 博河及精河流域内人口急剧增加, 为满足人类生活与经济发展需要, 博 河与精河流域中下游分布有大量农田,博乐市、温泉市及精河县附近的工业园区出现大批排污的高污染企 业. 加之春、夏季正处于农耕时期, 氮、磷肥的大量使用、灌溉用水的增加等一系列农业活动致使水体中 TN、 TP 等有机污染物浓度增高, 因而 TN、TP、COD 等有机污染物指标在春、夏季的浓度相对较高, 且高值多出现 于城镇及河流中下游区. 秋、冬季节天气变冷, 流域内如新疆腾博热力有限公司等热力公司排放的废物致使 秋、冬季人口聚居地水体有机物污染超标, 因此秋、冬季城镇附近及下游的 TN、TP、BOD 等有机污染指标相 对其他河段较高. 而部分下游及城镇附近水样金属离子和 SS 浓度的异常则与河流沿岸设立如精河县新石 石灰有限公司等矿业公司以及随水流汇集到下游的生活垃圾如农药瓶、洗涤用品等有关, SS 浓度在秋、冬季 总体小于人类活动频繁的春、夏季. 水中挥发酚浓度若大于 $5 \mathrm{mg} / \mathrm{L}$ 会导致鱼中毒死亡, 更不宜用于农田的 
灌溉,各季节挥发酚高值多出现于城镇附近,且秋、冬季相比夏季较高 (图 2、3), 这可能与河流沿岸设立的热 力公司及化工厂排放的废液有关,致使该处指标浓度异于其他河段. 结合数据可知挥发酚浓度超过 $5 \mathrm{mg} / \mathrm{L}$ 的水样来自于秋、冬、春季博河、精河人湖区. 艾比湖周边具有丰富的矿产资源, 石盐、镁盐、芒硝等初级工业 原料产量巨大, 在高温下裸露的湖床使得地表水蒸发速率加快, 水体中 $\mathrm{Mg}^{2+}$ 、硫酸盐及氯化物浓度升高, 故 $\mathrm{Mg}^{2+}$ 、硫酸盐及氯化物在艾比湖附近浓度较高. 值得注意的是, 流域夏季气温高, 加之精河流域处于阿拉尔 山口的下风处, 干燥大风天气易产生浮尘, 以颗粒形式存在于浮尘中的钠盐会造成当地肺部疾病、呼吸道疾 病、眼病及心血管疾病发病率升高.

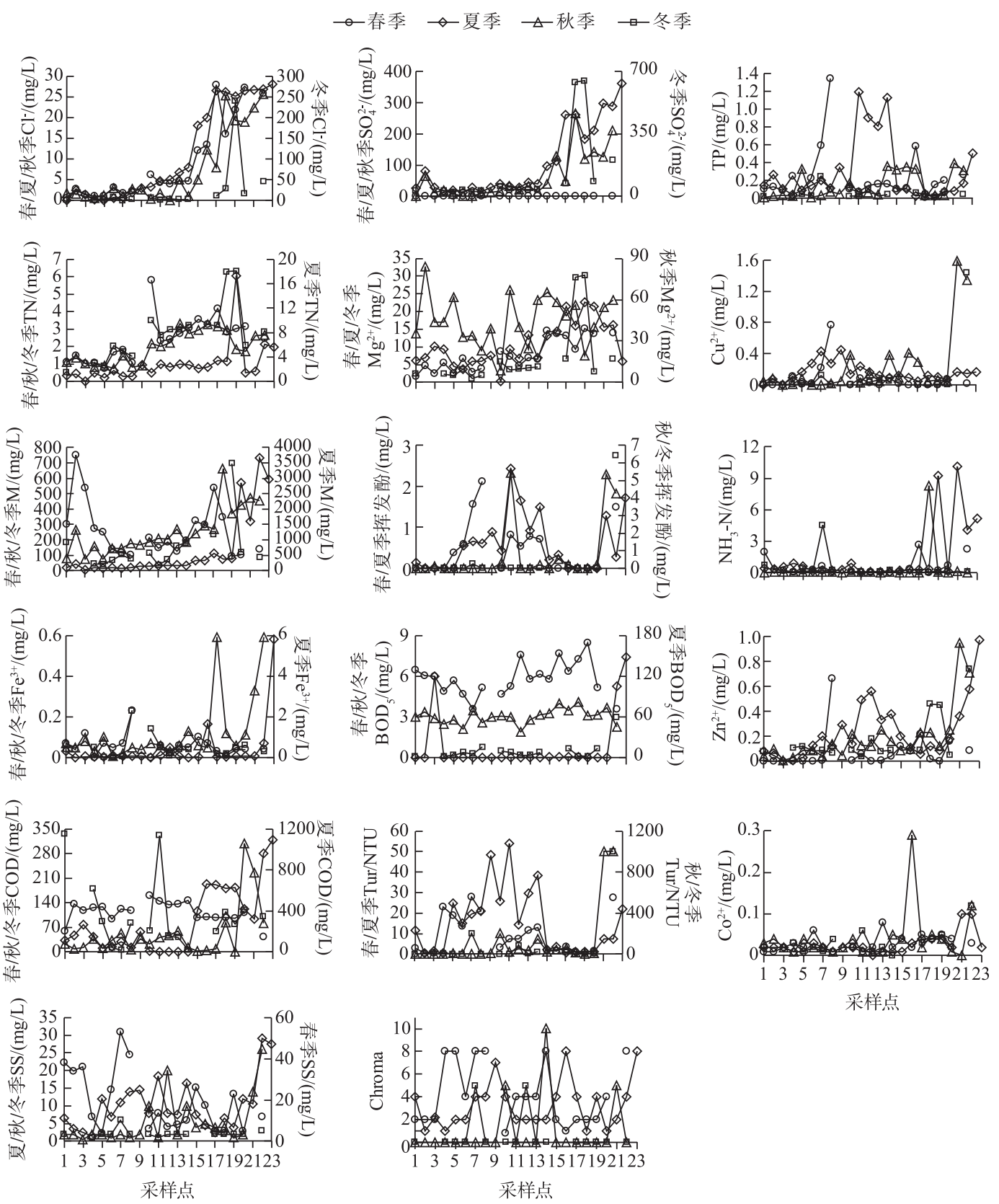

图 2 博尔塔拉河不同季节水质指标沿程分布

Fig.2 Distribution of water quality indexes in different seasons in Bortala River 


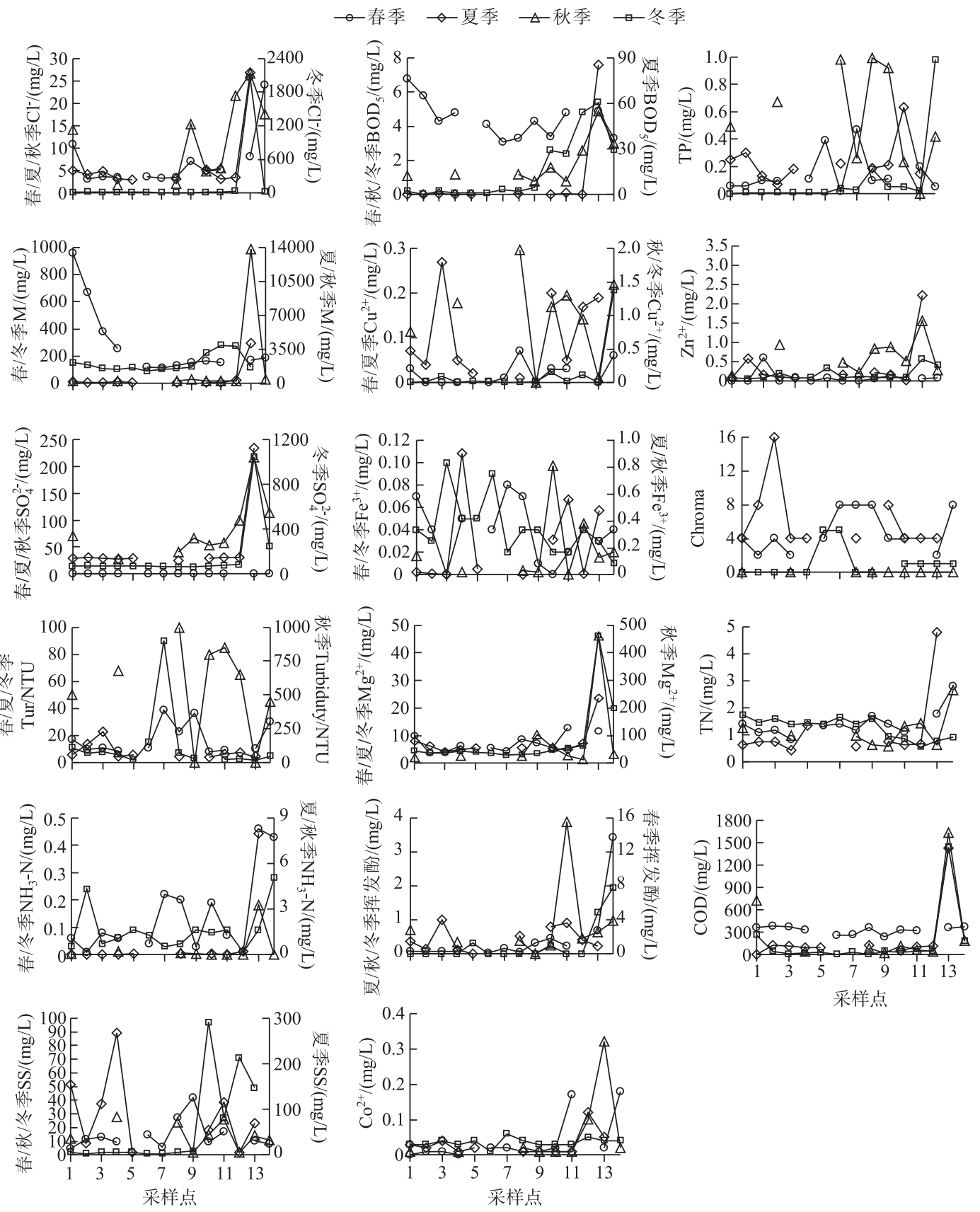

图 3 精河不同季节水质指标沿程分布

Fig.3 The distribution of water quality indexes in different seasons in Jinghe River

2.1.2 不同季节水质指标主成分分析 利用不同季节地表水水质指标数据 19 个变量组成的数据矩阵,在 Origin 9.1 统计软件下进行统计分析, 然后根据积累贡献率 $\geqslant 85 \%$, 提取主成分, 其特征值、贡献率及累积贡献 率见图 4 .

主成分分析表明,除秋季提取了 4 个主成分外,其余 3 个季节均提取了 6 个主成分, 其特征值均大于 1 , 其中秋季因子贡献率分别为 $40.45 \% 、 22.24 \% 、 9.52 \%$ 和 $6.77 \%$, 其累积贡献率达 $78.97 \%$; 春季因子贡献率分 
别为 $23.19 \% 、 18.43 \% 、 13.63 \% 、 9.25 \% 、 7.65 \%$ 和 $6.71 \%$, 其累积贡献率达 $78.86 \%$; 夏季因子贡献率分别为 $42.62 \% 、 23.58 \% 、 8.18 \% 、 7.23 \% 、 7.10 \%$ 和 $5.54 \%$, 其累积贡献率达 $94.25 \%$; 冬季因子贡献率分别为 $30.5 \%$ 、 $19.52 \% 、 12.6 \% 、 12.52 \% 、 6.4 \%$ 和 $5.64 \%$,其累积贡献率达 $87.18 \%$, 表明春、夏、秋 3 个季节前 6 个主成分提供 了原始数据的足够信息, 而秋季仅前 4 个主成分就提供了原始数据足够的信息. 进而求解主成分的载荷矩 阵 (表 2), 载荷系数越大,其水质指标对水环境影响越大, 起到主导作用.
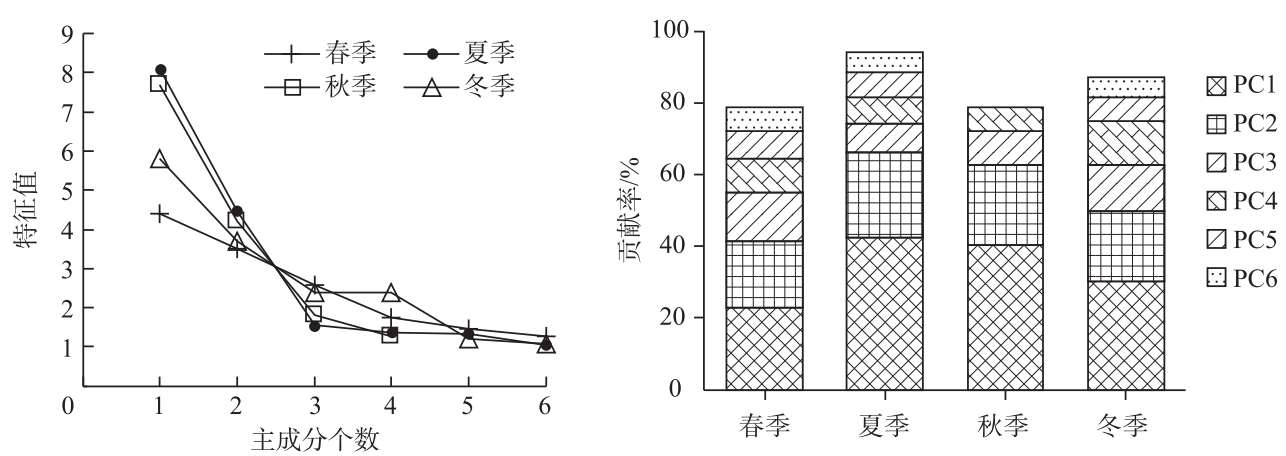

图 4 不同季节的水质指标碎石图及方差图

Fig.4 The lithotripsy and variance diagram of water quality index in different seasons

选取载荷系数最大的因子变量, 其中春季: $\mathrm{F} 1$ 的表征因子为 $\mathrm{Cu}^{2+}$ 、挥发酚、 $\mathrm{TP} 、 \mathrm{Fe}^{3+}$ 和 $\mathrm{SS}$, 均呈正相关, 此 类主要来源为各化工企业污染排放物以及城镇生活废水的排放; F2 的表征因子为氯化物和 $\mathrm{Mg}^{2+}$, 呈正相 关, 其主要来源为镁盐的开采; F3 表征因子为 COD, 呈正相关, 色度和浊度呈负相关, 说明它们之间相互影 响, 因此 F3 代表有机物污染源, 随污染加重, 水体的色度浊度呈现负增加; F4 的表征因子为钴和硫酸盐, 呈 正相关, 其与 F2 均来源于艾比湖流域如芒硝等丰富的矿产资源; F5 的表征因子为矿化度 (M) 和 $\mathrm{Zn}^{2+}$, 呈正 相关, 其来源为工矿企业所产生的废液; $\mathrm{F} 6$ 的表征因子为 $\mathrm{BOD}_{5}$, 呈正相关, 其与 $\mathrm{F} 3$ 同为生物、化学需氧量的 相关污染指标,二者主要与有机物相关的生活用水和第三产业废水的排放有关.

夏季: F1 的表征因子为 $\mathrm{COD}$ 、氯化物、硫酸盐、矿化度、BOD $、 \mathrm{NH}_{3}-\mathrm{N} 、 \mathrm{Zn}^{2+} 、 \mathrm{Co}^{2+}$ 和 $\mathrm{Mg}^{2+}$, 呈正相关, 除 $\mathrm{BOD}_{5}$ 与矿化度具有较高的相关性, 其余各指标间相关性不大, 说明指标间相互不影响, 主要来源于流域内丰 富的矿产资源以及工矿企业所产生的废液; F2 的表征因子为挥发酚、浊度和 TP, 呈正相关, 与夏季生活用水 增加及第三产业有关; $\mathrm{F} 3$ 的表征因子为 $\mathrm{Cu}^{2+} 、 \mathrm{Mg}^{2+}$, 呈正相关, 来源于流域内的矿产资源 (铜矿和镁盐); F4 的表征因子为色度; F5 的表征因子为悬浮物, 呈负相关, 与其余水质指标相关性极低, 可能与其在夏季复杂 的来源有关, 比如工业废水、生活用水、灌溉用水以及气候变化等均可使其浓度增加; $\mathrm{F} 6$ 为 $\mathrm{TN}$ 和 $\mathrm{NH}_{3}-\mathrm{N}$, 呈 正相关, 同 F2 均为季节性污水排放的营养物质过量, 其来源于如番茄加工厂等生物原料污水的排放以及耕 期化肥的大量使用.

秋季: $\mathrm{F} 1$ 的表征因子为 $\mathrm{BOD}_{5} 、 \mathrm{COD} 、 \mathrm{NH}_{3}-\mathrm{N}$ 、矿化度、氯化物和硫酸盐, 均呈正相关, 与夏季 $\mathrm{F} 1$ 相似, 其 主要来源为精河县艾比湖工业园区生产的芒硝和湖盐和在生产过程中所产生的废液; F2 的表征因子为浊 度、 $\mathrm{Cu}^{2+}$ 、悬浮物、和 $\mathrm{TP}$, 均呈正相关, 主要为沿岸城市产生的生活垃圾以及工矿企业对水体造成的影响; F3 的表征因子为浊度, 呈正相关, 说明其他污染致使水体变浑浊; $\mathrm{F} 4$ 的表征因子为挥发酚和 $\mathrm{Fe}^{3+}$, 均呈正相关, 根据博尔塔拉政府网 (http://www.xjboz.gov.cn/info/1544/154879.htm) 公布的 2017 年下半年博州非煤矿山 企业情况统计表可知, 研究区有新疆盛泰金源矿业有限公司, 推断秋季及冬季该类因子主要源于该公司开 采铁矿、铜矿所产生的废水、废料排放.

冬季: $\mathrm{F} 1$ 的表征因子为 $\mathrm{BOD}_{5} 、 \mathrm{COD} 、 \mathrm{Mg}^{2+} 、 \mathrm{Zn}^{2+}$ 、氯化物和硫酸盐, 均为正相关, 与夏季的 F1 相似; F2 的 表征因子为浊度、挥发酚和 $\mathrm{Cu}^{2+}$, 与秋季的 F4 相似, 主要来源于开采铜矿时所产生的废液; F3 的表征因子为 $\mathrm{NH}_{3}-\mathrm{N}$ 和 $\mathrm{TP}, \mathrm{F} 4$ 的表征因子为 $\mathrm{TN}$, 呈负相关, 与 $\mathrm{F} 3$ 均来源于人类日常活动所造成的污染; $\mathrm{F} 5$ 的表征因子为 $\mathrm{Fe}^{3+}, \mathrm{F} 6$ 为悬浮物和矿化度, 呈正相关, 主要来源于热力公司冬季供暖过程所产生的废液. 
依据因子分析,在各季节精河、博河主要受到的污染为水体富营养化 ( TP、TN 和 $\mathrm{NH}_{3}-\mathrm{N}$ )、有机物污染 $\left(\mathrm{BOD}_{5} 、 \mathrm{COD}\right) 、$ 工矿业污染 $\left(\mathrm{Cu}^{2+} 、 \mathrm{Mg}^{2+}\right.$ 、挥发酚、矿化度、氯化物和硫酸盐) 以及物理污染 (悬浮物), 而河流 地表水氢氧同位素于各季节均与 $\mathrm{NH}_{3}-\mathrm{N}$ 为同一主成分, 且其所占比重为夏秋>春、冬. 由于不同季节污染源 有所不同 (夏、秋季多来源于化肥、农副产品以及矿产资源, 春冬季多来源于供暖以及工矿企业), 故不同季 节各主成分间即有相似, 又有不同之处,一般夏季污染情况最为严重,其次为秋、春、冬季. 研究区内水环境 治理工作需针对不同季节的污染来源进行分季治理, 并着重在污染源复杂的夏季对精河、博河的水环境进 行治理.

\section{表 2 不同季节的水质指标主成分载荷矩阵}

Tab.2 The principal component load matrix of water quality in different seasons

\begin{tabular}{|c|c|c|c|c|c|c|c|c|c|c|c|c|c|c|c|c|c|c|c|c|c|c|}
\hline \multirow{2}{*}{ 指标 } & \multicolumn{6}{|c|}{ 春季 } & \multicolumn{6}{|c|}{ 夏季 } & \multicolumn{4}{|c|}{ 秋季 } & \multicolumn{6}{|c|}{ 冬季 } \\
\hline & $\mathrm{F} 1$ & $\mathrm{~F} 2$ & F3 & F4 & F5 & F6 & $\mathrm{F} 1$ & F2 & F3 & $\mathrm{F} 4$ & F5 & F6 & $\mathrm{F} 1$ & F2 & F3 & F4 & $\mathrm{F} 1$ & $\mathrm{~F} 2$ & F3 & F4 & F5 & F6 \\
\hline$\delta^{2} \mathrm{H}$ & -0.60 & 0.62 & 0.34 & 0.02 & -0.13 & -0.09 & 0.94 & 0.23 & -0.07 & 0.03 & -0.13 & -0.10 & 0.79 & 0.04 & -0.37 & -0.25 & 0.33 & -0.27 & 0.65 & -0.25 & -0.52 & -0.20 \\
\hline$\delta^{18} 0$ & -0.59 & 0.63 & 0.35 & 0.02 & -0.10 & -0.11 & 0.94 & 0.24 & -0.09 & -0.01 & -0.14 & -0.09 & 0.84 & 0 & -0.37 & -0.23 & 0.44 & -0.26 & 0.59 & -0.30 & -0.47 & -0.17 \\
\hline SS & 0.61 & 0.08 & 0.04 & -0.13 & -0.50 & -0.38 & -0.43 & 0.45 & -0.29 & 0.18 & -0.50 & 0.36 & 0.13 & 0.84 & 0.13 & -0.30 & 0.53 & $-0.33-$ & -0.15 & 0.42 & -0.30 & 0.54 \\
\hline $\mathrm{BOD}_{5}$ & $-0.31-$ & -0.02 & 0.36 & -0.11 & -0.27 & 0.62 & 0.78 & 0.52 & -0.29 & -0.06 & 0.04 & 0.04 & 0.75 & -0.41 & 0.02 & 0.34 & 0.77 & $-0.06-$ & -0.20 & 0.39 & -0.22 & 0.35 \\
\hline TN & -0.54 & 0.25 & 0.28 & -0.27 & 0.13 & 0.18 & 0.50 & -0.18 & 0.53 & -0.08 & 0.27 & 0.57 & 0.67 & -0.02 & 0.40 & 0.43 & 0.12 & 0.10 & 0.38 & -0.70 & 0.45 & 0.12 \\
\hline Tur & 0.17 & 0.51 & -0.65 & -0.34 & 0.07 & 0.34 & -0.29 & 0.84 & 0.39 & -0.13 & 0.05 & -0.14 & -0.10 & 0.97 & 0 & 0.03 & 0.43 & 0.88 & 0.12 & 0.07 & 0.02 & -0.04 \\
\hline Chr & 0.24 & 0.53 & -0.58 & -0.32 & 0.04 & 0.33 & -0.14 & 0.36 & -0.23 & 0.62 & 0.61 & 0.07 & 0.30 & 0.08 & 0.56 & 0.33 & -0.06 & 0 & 0.57 & 0.44 & 0 & -0.16 \\
\hline M & $-0.02-$ & -0.41 & 0.04 & -0.22 & 0.60 & -0.26 & 0.84 & 0.37 & -0.12 & 0.20 & -0.30 & 0.01 & 0.87 & -0.06 & 0.41 & -0.11 & 0.30 & -0.27 & 0.31 & -0.55 & 0.18 & 0.58 \\
\hline $\mathrm{NH}_{3}-\mathrm{N}$ & 0.21 & 0.35 & -0.18 & -0.40 & -0.49 & -0.33 & 0.76 & 0.07 & 0.28 & 0.08 & 0.04 & 0.57 & 0.83 & -0.11 & 0.07 & $-0.02-$ & -0.13 & 0.10 & 0.65 & 0.56 & 0.26 & 0.05 \\
\hline COD & $-0.14-$ & -0.19 & 0.77 & 0.01 & -0.19 & 0.27 & 0.96 & 0 & -0.12 & 0.02 & 0.01 & 0.01 & 0.87 & 0.04 & 0.01 & -0.28 & 0.70 & $-0.41-$ & -0.28 & 0.30 & 0.18 & -0.28 \\
\hline $\mathrm{TP}$ & 0.68 & 0.56 & 0.27 & 0.06 & 0.01 & $-0.01-$ & -0.24 & 0.80 & 0.35 & -0.38 & -0.16 & -0.08 & -0.16 & 0.83 & 0.22 & -0.24 & -0.15 & 0.14 & 0.62 & 0.58 & 0.21 & 0.17 \\
\hline $\mathrm{Fe}^{3+}$ & 0.61 & 0.29 & 0.40 & -0.11 & 0.10 & -0.18 & 0.40 & 0.51 & -0.45 & -0.39 & 0.44 & 0.14 & 0.03 & 0.51 & -0.21 & 0.43 & -0.15 & -0.04 & -0.23 & -0.20 & -0.06 & -0.10 \\
\hline $\mathrm{Zn}^{2+}$ & 0.45 & 0.35 & 0.31 & 0.16 & 0.56 & -0.03 & 0.66 & 0.45 & -0.01 & 0.14 & -0.38 & 0.07 & 0.84 & 0.34 & 0.28 & -0.16 & 0.87 & 0.34 & 0.08 & -0.10 & 0.15 & -0.12 \\
\hline $\mathrm{C}_{0}^{2+}$ & -0.27 & 0.25 & -0.15 & 0.68 & -0.20 & -0.16 & 0.65 & -0.03 & 0.22 & 0.46 & -0.03 & -0.25 & 0.70 & -0.03 & -0.26 & -0.07 & 0.58 & $0.59-$ & -0.14 & -0.20 & -0.22 & 0.06 \\
\hline $\mathrm{Cu}^{2+}$ & 0.72 & 0.43 & 0.45 & 0.07 & 0.07 & 0.08 & 0.13 & 0.68 & 0.44 & 0.38 & 0.24 & -0.26 & -0.11 & 0.94 & 0.03 & 0.01 & 0.46 & 0.87 & 0 & 0.01 & -0.03 & 0.04 \\
\hline $\mathrm{Mg}^{2+}$ & -0.60 & 0.60 & -0.14 & 0.25 & 0.13 & -0.10 & 0.59 & -0.60 & 0.42 & -0.07 & -0.16 & -0.10 & 0.84 & -0.06 & 0.46 & -0.08 & 0.84 & -0.45 & 0.03 & -0.11 & 0.26 & -0.03 \\
\hline 挥发酚 & 0.70 & 0.42 & 0.03 & 0.29 & 0.04 & 0.29 & -0.30 & 0.91 & $0.13-$ & -0.24 & 0.08 & 0.01 & 0 & 0.56 & -0.06 & 0.44 & 0.60 & 0.78 & -0.05 & 0.03 & 0.01 & -0.07 \\
\hline 氯化物 & -0.54 & 0.70 & -0.16 & -0.07 & 0.23 & -0.21 & 0.85 & -0.36 & $0.03-$ & -0.24 & 0.20 & -0.18 & 0.71 & 0.26 & -0.46 & 0.26 & 0.79 & $-0.46-$ & -0.12 & 0.25 & 0.15 & -0.24 \\
\hline 硫酸盐 & $0.19-$ & -0.05 & -0.41 & 0.75 & -0.08 & 0.15 & 0.87 & -0.10 & $-0.11-$ & -0.30 & 0.19 & -0.18 & 0.76 & 0.24 & -0.47 & 0.21 & 0.88 & -0.39 & 0.05 & -0.09 & 0.22 & -0.09 \\
\hline
\end{tabular}

* 加粗数字表示在该因子下具有较高影响的水体指标.

\section{2 主要入湖河流地表水氢氧同位素组成}

2.2.1 入湖河流地表水 $\delta^{18} \mathrm{O} 、 \delta^{2} \mathrm{H}$ 间的关系 图 5 为艾比湖流域不同季节的 $\delta^{18} \mathrm{O}-\delta^{2} \mathrm{H}$ 关系. 其中全大气降 水线 (GMWL) 采用 IAEA 的全大气降同位素方程 $\left(\delta^{2} \mathrm{H}=8.14 \delta^{18} \mathrm{O}+10.9\right)$ 建立 ${ }^{[39]}$, 应用多年多站观测的多组 氢氧同位素组分建立的乌鲁木齐大气降水线 $\mathrm{LMWL}$ 为 $\delta^{2} \mathrm{H}=6.98 \delta^{18} \mathrm{O}+0.44^{[40]}$. 从流域水 $\delta^{18} \mathrm{O}-\delta^{2} \mathrm{H}$ 关系 (图 5) 可以看出, $\delta^{18} \mathrm{O}$ 与 $\delta^{2} \mathrm{H}$ 存在明显的线性关系, 其相关性为夏季 $\left(\delta^{2} \mathrm{H}=5.31 \delta^{18} \mathrm{O}-11.63, R^{2}=0.99\right)>$ 春 季 $\left(\delta^{2} \mathrm{H}=6.59 \delta^{18} \mathrm{O}+0.99, R^{2}=0.98\right)>$ 秋季 $\left(\delta^{2} \mathrm{H}=5.11 \delta^{18} \mathrm{O}-18.62, R^{2}=0.96\right)>$ 冬季 $\left(\delta^{2} \mathrm{H}=5.83 \delta^{18} \mathrm{O}-10.97\right.$, $\left.R^{2}=0.90\right)$, 均沿当地大气降水线分布, 再次证明大气降水是人湖河水地表水的来源之一, 但由于研究区干旱 高温, 河水的氢氧同位素受蒸发作用影响大, 尤其是人湖处蒸发作用更加明显 ${ }^{[41]}$. 春、夏、秋、冬 4 个季节的 方程线分居全球大气降水线 (GMWL) 和当地大气降水线 ( LMWL) 两侧, 它们的斜率和截距大小表现为: 全 球大气降水线 $(k=8.14)>$ 当地大气降水线 $(k=6.98)>$ 春季 $(k=6.59)>$ 冬季 $(k=5.83)>$ 夏季 $(k=5.31)>$ 秋季 $(k=5.11)$. 水体一般蒸发线的斜率会随着蒸发作用的加强而减小, 研究区流域内水体的蒸发线斜率均小于 8 , 表现出降雨量小而蒸发量大的干旱区特征 ${ }^{[41]}$. 通过比较研究区不同季节蒸发线的斜率, 可以发现蒸发强 烈程度为:秋季>夏季>冬季>春季. 

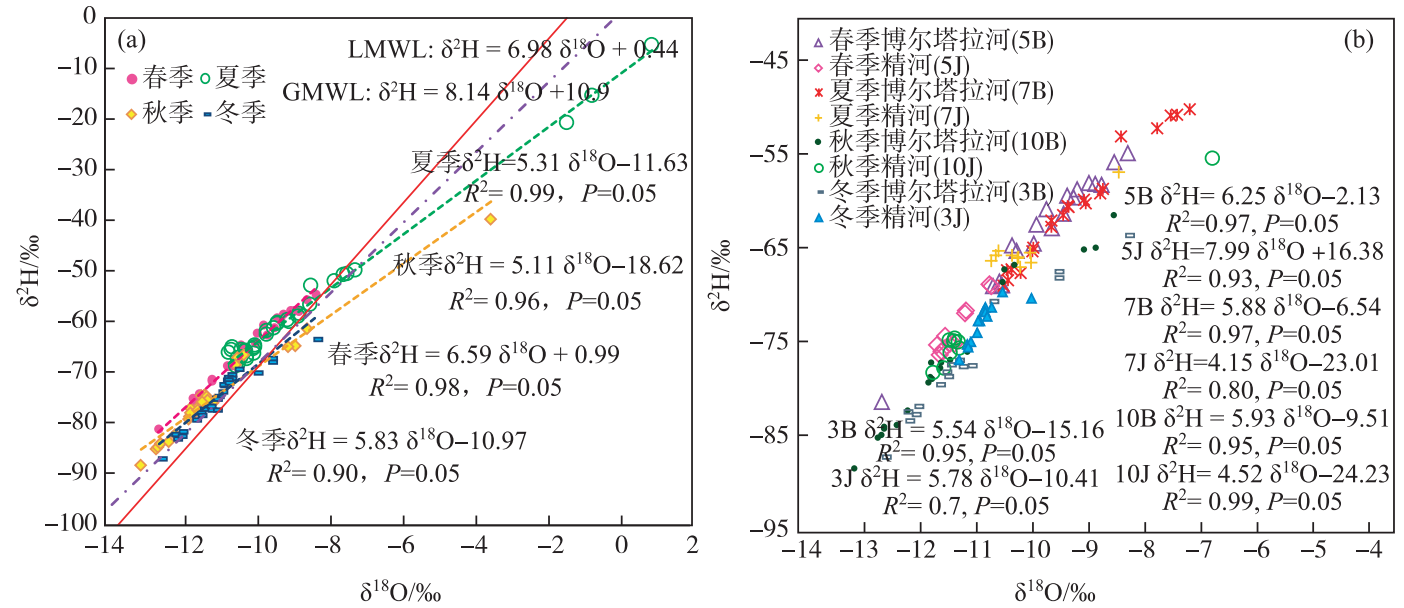

图 5 不同季节主要人湖河流氢氧同位素关系

Fig.5 Relationship between hydrogen and oxygen isotopic of main rivers entering lake in different seasons

除秋季、夏季共 4 个点于降水线右下方外,其他样点均分布于降水线左上方 (图 5a), 结合数据可知这 4 个离群点采于精河、博河人湖口处, 这是由于一般河水 $\delta^{18} \mathrm{O}$ 值低于湖水, 而艾比湖周边有大片盐碱地, 夏季 气温高, 蒸发量大, 导致夏季河流人湖口处水样中的 $\delta^{18} \mathrm{O} 、 \delta^{2} \mathrm{H}$ 含量均高于其他采样点. 排除夏季和秋季 4 个异于其他样点的水样后, 得出博河、精河地表水样 $\delta^{18} \mathrm{O}$ 值范围为 $-13 \%{ }_{0} \sim-6 \%, \delta^{2} \mathrm{H}$ 值范围为 $-92 \% 0 \sim$ $-47 \%$ (图 5b). 稳定氢氧同位素在图中呈离散带状分布, 表明各水体来源与不同季节和不同河段有差异,但 大部分水体之间的水力联系紧密. 稳定氢氧同位素组成最为富集的水体分布于图的右上方,查找数据可知, 位于夏季博河下游及冬季精河下游水样的氢氧同位素组成最为富集, 由于受到强烈的蒸发, 水体中的氢氧 同位素组成较为富集. 而在图中左下角最为贫化的水样均于冬、春、秋季气温低时所采集,这是因为秋、冬季 为枯水期,降水量少,河流地表水补给来源于 $\delta^{18} \mathrm{O} 、 \delta^{2} \mathrm{H}$ 贫化的冰雪融水.

氞过量参数又称氞盈余, 是 Dansgaard ${ }^{[42]}$ 提出的新概念, 定义为: $d$-excess $=\delta^{2} \mathrm{H}-8 \delta^{18} \mathrm{O} . d$-excess 值的大 小反映该地区水一岩氧同位素交换程度, 当降水进人含水层之后由于水与岩石发生同位素交换会导致 $d$ excess 值发生变化 ${ }^{[43]}$. 为便于研究河流気过量参数特征的讨论, 根据 Dansgaard ${ }^{[42]}$ 提出的方程将 $d$-excess 值 为 30\%、、25\%。、20\%、15\%。、10\%。、5\%和 0 时的特征绘出（图 6), 从中可知春季 $d$-excess 值的范围为 $11.3 \%$ $19.12 \%$, 平均为 $15.4 \%$; 夏季除去 $d$-excess 值小于 0 的博河 B $21 、$ B 22 及精河 $\mathrm{J} 10$ 后, 其余采样点 $d$-excess 值 的范围为 7.35\% 19.06\% , 平均为 $13.73 \%$; 秋季去除 $d$-excess 值为- $12.18 \%$ 的精河 J8 外, 其余水样 $d$-excess 值的范围为 $5.65 \% 0 \sim 16.436 \%$, 平均为 $14.17 \%$; 冬季 $d$-excess 值的范围为 $2.83 \% 0 \sim 14.98 \%$, 平均 $12.78 \%$, 博 河 B21、B22 及精河 J10、J8 四个点位于艾比湖人湖口处(图 1), 由于咸水湖水体蒸发强烈的特征, 这几处水 样点于夏、秋季 (蒸发量大) 的 $d$-excess 值小于 0 . 研究河流水体的季节性变化按其 $d$-excess 均值表现为春季 $(15.4 \% 0)>$ 秋季 $(14.17 \% 0)>$ 夏季 $(13.73 \% 0)>$ 冬季 $(12.78 \% 0), d$-excess 值的差异主要是由于春季地下水和降 雨为河流主要补给来源, 而地下水来源于冰雪融水, 受蒸发分馏的影响, 其 $d$-excess 值偏高 ${ }^{[4-45]}$; 而夏季由于 气候干燥, 其降水受区域性蒸发水汽影响明显, 使得河水中过量気偏低; 艾比湖地区处于西风带, 受季风影 响很弱, 冬季受源于大西洋的西风带强烈南移及其气旋风加强影响, 带来较多的水汽气温下降 ${ }^{[46]}$, 降雨量 大,且蒸发量低,地表水补给多来源于降水, 故 $d$-excess 值偏低.

2.2.2 入湖河流氢氧同位素组成的沿程变化 从上游到下游, 河水氢氧同位素组成受地形、人为活动和气候 等影响,小流域河流的空间分布为上述某些影响的集中表现. 图 7 显示出艾比湖主要人湖河流的 $\delta^{18} O 、 \delta^{2} \mathrm{H}$ 值沿流程方向的变化情况. 总体来说, 除个别样点, 各季节地表水的 $\delta^{18} \mathrm{O} 、 \delta^{2} \mathrm{H}$ 组成都从上游到下游逐渐偏 正, 表明上游地区靠近山区, 河水主要来源于冰川补给, 而中、下游地区为平坦的盆地, 主要源于降水补给, 加之降雨到达地面后在产生地表径流或下渗的过程中均会遭遇地面蒸发而使其同位素发生变化, 蒸发过程 


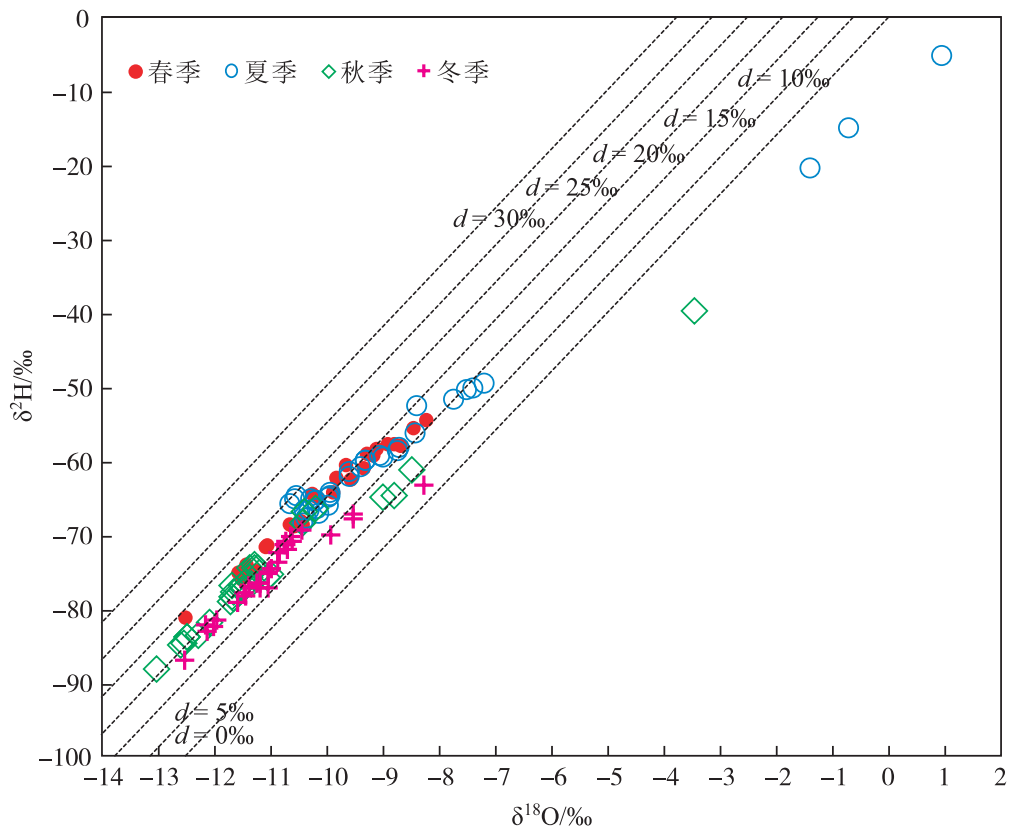

图 6 不同季节主要人湖河流 $d$-excess 值分布

Fig. 6 The distribution of the $d$-excess value of the main rivers entering the lake in different seasons

中同位素相对较轻的水汽会先蒸发, 剩余的水体富集重同位素 ${ }^{[45,47-49]}$, 故越靠近下游地区氢氧同位素偏正, 又因博河较之精河要长, 故其变化更加明显. 博河 $\mathrm{B} 2$ 点位于温泉县附近,其 $\delta^{18} \mathrm{O} 、 \delta^{2} \mathrm{H}$ 值在各季均高于其上 下游的值, 这可能与温泉县矿产资源丰富, 水一作用使得 $\delta^{18} \mathrm{O} 、 \delta^{2} \mathrm{H}$ 值偏正有关. 秋、冬季节博河 B7、B10、 B18 B20 这 5 个点均高于其上下游, 但其在夏、秋季节差异并不大, 结合研究区图可知, 这几个点分别位于 博乐市、及一些分布有城镇的河流支流, 表明在季节变化 ( 冬、秋季气候干燥, 降雨量少, 而春、夏季为丰水 期, 降雨量多) 和人类干扰的影响下 $\delta^{18} \mathrm{O} 、 \delta^{2} \mathrm{H}$ 值有所改变. 而精河由于其上游到下游海拔差异不大, 流程简 短, 其变化趋势较为稳定, 只有 $\mathrm{J} 13$ 在夏、秋季出现高值, 且秋季大于夏季, 这是由于 $\mathrm{J} 13$ 点位于精河入湖口, 该处周边有大片盐碱地, 且位于阿拉尔山口的下风处,蒸发量大,加之夏季为农耕时节, 灌溉量增加, 秋季风 大, J13 处水量降至一年最低, 故该处 $\delta^{18} O 、 \delta^{2} H$ 出现高值.

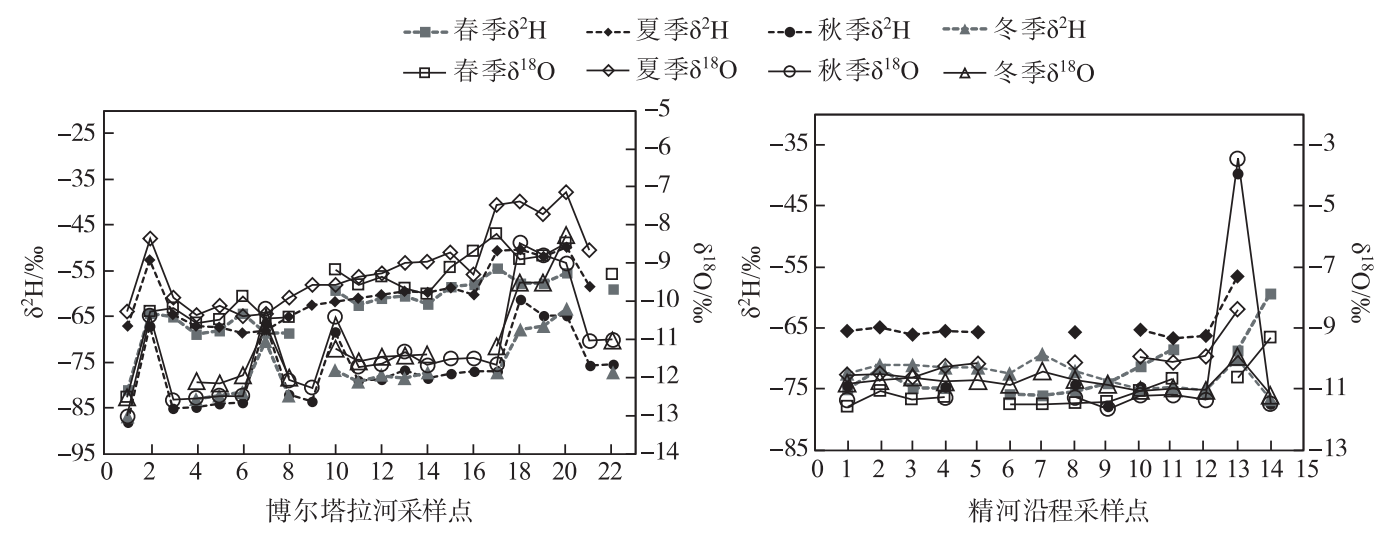

图 7 博尔塔拉河和精河不同季节 $\delta^{18} \mathrm{O} 、 \delta^{2} \mathrm{H}$ 沿程变化

Fig.7 The variation of $\delta^{18} \mathrm{O}$ and $\delta^{2} \mathrm{H}$ in different seasons in Bortala River and Jinghe River 
2.2.3 入湖河流地表水 $\delta^{18} \mathrm{O}$ 值高程变化趋势 为消除局地环境多水样 $\delta^{18} \mathrm{O}$ 水文影响, Deshpande 等 ${ }^{[50]}$ 、 Dotsika 等 ${ }^{[51]}$ 和丁林等 ${ }^{[52]}$ 均建立了 $\delta^{18} \mathrm{O}$ 值与海拔高度 $(\mathrm{H})$ 的回归方程, 来消除局地环境对 $\delta^{18} \mathrm{O}$ 值的影响, 故本文仅对 $\delta^{18} \mathrm{O}$ 值与高程间的关系进行了研究. $\delta^{18} \mathrm{O}$ 值与海拔高度的回归方程 (图 8) 显示, 不同季节博河 水体 $\delta^{18} \mathrm{O}$ 值与海拔高度表现出一定的负相关关系, 海拔越高 $\delta^{18} \mathrm{O}$ 值越偏轻, 其相关性的季节差异为春季 $\left(\delta^{18} \mathrm{O}=-0.002 \mathrm{H}-8.272, R^{2}=0.7\right)>$ 冬季 $\left(\delta^{18} \mathrm{O}=-0.002 \mathrm{H}-9.603, R^{2}=0.57\right)>$ 夏季 $\left(\delta^{18} \mathrm{O}=-0.001 \mathrm{H}-7.971\right.$, $\left.R^{2}=0.45\right)>$ 秋季 $\left(\delta^{18} \mathrm{O}=-0.001 \mathrm{H}-10.074, R^{2}=0.3\right)$, 精河因其海拔差异不大, 流程简短, 其相关性较低: 春季 $\left(\delta^{18} \mathrm{O}=-0.002 \mathrm{H}-10.479, R^{2}=0.2\right)>$ 夏季 $\left(\delta^{18} \mathrm{O}=-0.002 \mathrm{H}-6.313, R^{2}=0.22\right)>$ 秋季 $\left(\delta^{18} \mathrm{O}=-0.006 \mathrm{H}-8.302\right.$, $\left.R^{2}=0.11\right)$, 冬季基本没有相关性 $\left(R^{2}=0.001\right)$, 且其与高程呈线性正相关 $\left(\delta^{18} \mathrm{O}=-0.0001 \mathrm{H}-10.796\right)$.

综上所述, 博河与精河地表水体 $\delta^{18} \mathrm{O}$ 值与高程均表现出一定的负相关关系, 海拔越高 $\delta^{18} 0$ 值越偏负, 这主要与低海拔地区地表水补给来源于大气降水, $\delta^{18} \mathrm{O}$ 受降水同位素偏正的影响而偏正, 而高海拔地区地 表水补给多源于山上的冰川融水, $\delta^{18} \mathrm{O}$ 受冰雪融水同位素偏负的影响而偏负有关. 博河精河体 $\delta^{18} O$ 值与高 程相关性的季节特征为春季相关性最高, 夏季虽大于秋季, 但差异不大, 这是由于春季流域内河流地表水补 给来源多为冰雪融雪, 故高程与 $\delta^{18} \mathrm{O}$ 相关性高, 而夏、秋季为丰水期, 流域内河流地表水补给不仅有地下水 还有降雨, 而低海拔地区降雨量随高程变化并不明显, 故相关性较之春季有所降低, 且夏、秋均为耕期, 其相 关性接近. 博河和精河水体 $\delta^{18} \mathrm{O}$ 值的高度趋势在一定程度上反映艾比湖流域降水、地下水的高度效应, 这对 流域水循环过程的研究具有重要的水文地质意义.

精河 $\mathrm{H} / \mathrm{m}$

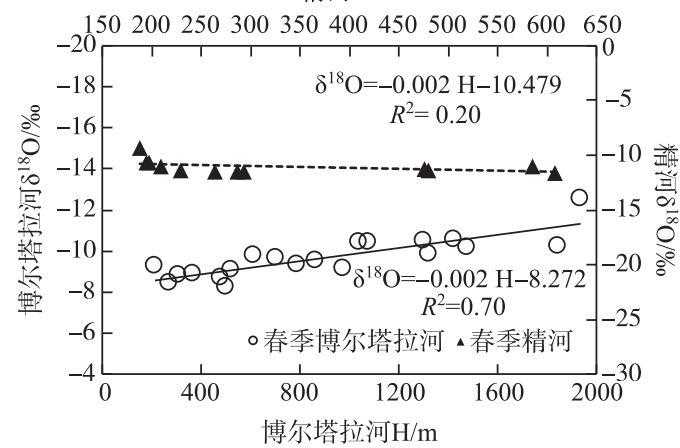

精河 $\mathrm{H} / \mathrm{m}$

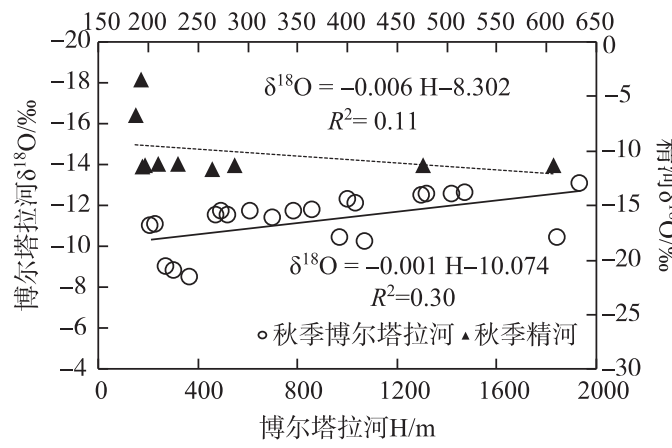

精河 $\mathrm{H} / \mathrm{m}$

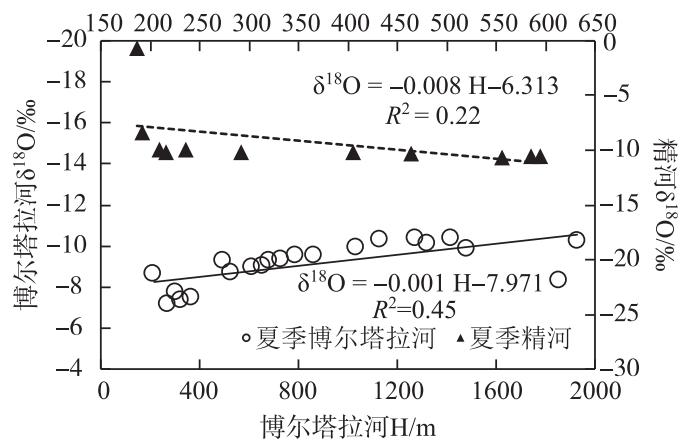

精河 $\mathrm{H} / \mathrm{m}$

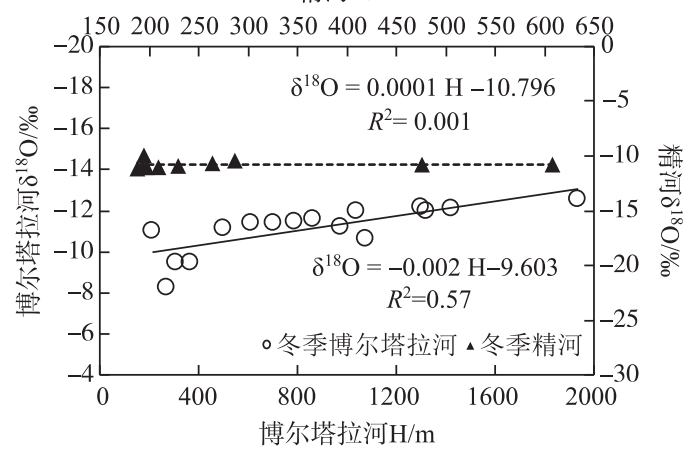

图 $8 \delta^{18} \mathrm{O}$ 与高程的线性相关

Fig. 8 The linear correlation between $\delta^{18} \mathrm{O}$ and elevation

\section{3 入湖河流水体水化学特征与氢氧同位素的相关性分析}

河水中氢氧同位素组成的时空变化受到流域地形、气候和人类活动的制约,是对流域内降水、冰雪融 水、地下水等补给源的氢氧同位素特征以及河水所受蒸发影响的综合响应 ${ }^{[13]}$. 艾比湖主要人湖河流精河与 博河地表水氢氧同位素与水质指标有一定的相关性(图 9), 且其季节性差异明显. 

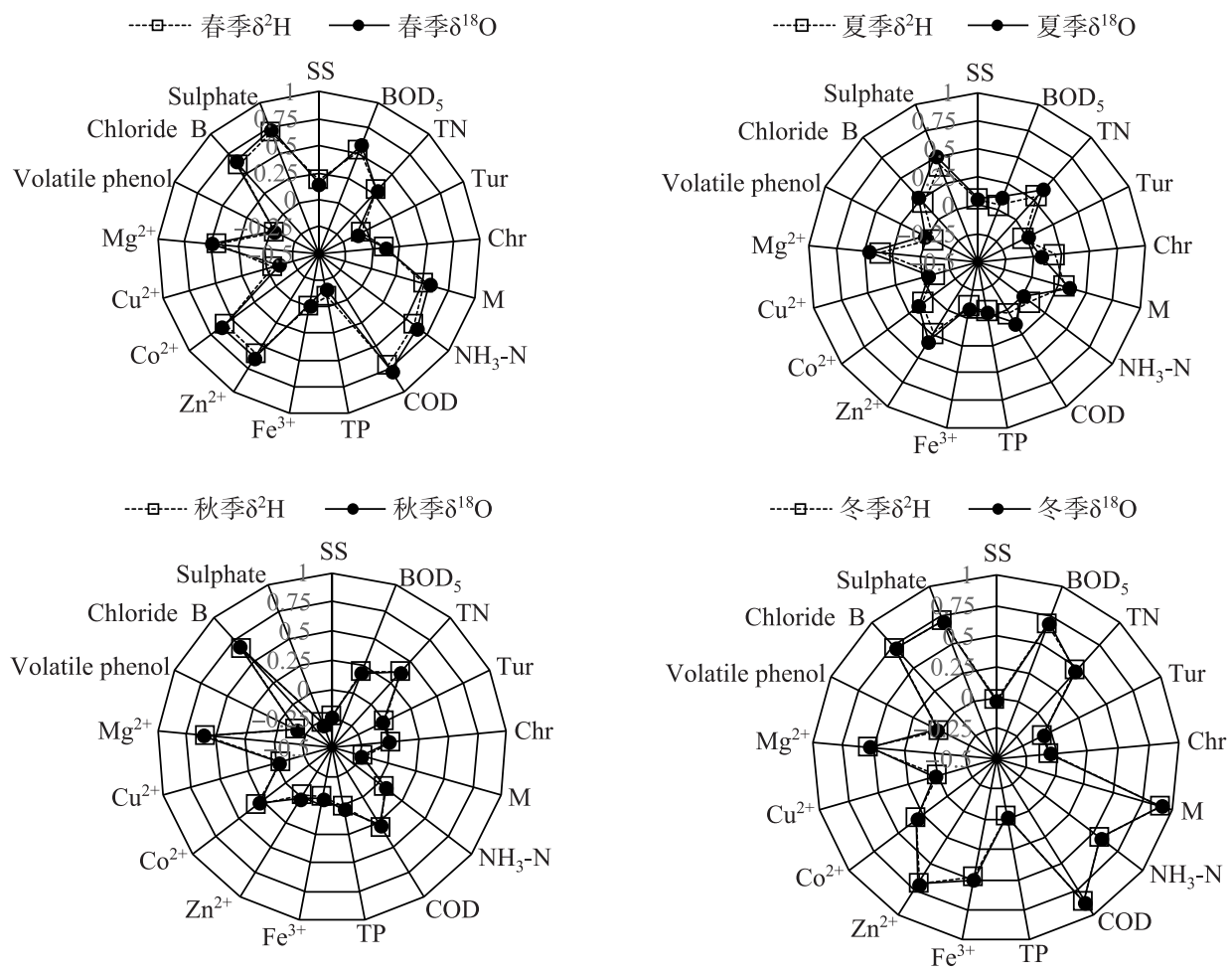

图 9 不同季节氢氧同位素与水质指标的相关系数 $R$

Fig.9 The correlation coefficients $(R)$ between $\delta^{18} \mathrm{O}, \delta^{2} \mathrm{H}$ and water quality indexes in different seasons

春季:氢氧同位素与氯化物、COD、 $\mathrm{BOD}_{5}$ 的相关性较之冬季有所增加, 与硫酸盐和矿化度的相关性反而 降低至 0 以下, 这可能与人类活动有关. 夏季: 氢氧同位素与大多水质指标的相关性有所增加, 其中与 COD 和 $\mathrm{Mg}^{2+}$ 相关性显著, 其次为氯化物、硫酸盐和 $\mathrm{BOD}_{5}$, 这些指标为生物指标及艾比湖周边盐田中 (芒硝、镁盐) 所含离子, 表明夏季氢氧同位素受人为干扰及气候变化、蒸发作用及水一岩作用的影响. 秋季: 氢氧同位素与 各指标间相关性有所降低, 与硫酸盐的相关性最高, 其次为 COD 、氯化物、氨氮, 与夏季具有相似性. 冬季: 氢 氧同位素与各指标间的相关性最低, 均在 0.5 以下, 与 $\mathrm{Cu}^{2+} 、 \mathrm{Fe}^{3+}$ 和 TP 均呈负相关, 说明冬季博河与精河地 表水同位素主要受补给来源影响,蒸发作用的影响相对较小.

综上所述,博河和精河氢氧同位素与水体中氯化物、硫酸盐、 $\mathrm{BOD}_{5}$ 等有机和盐分指标间均存在相关性, 且在夏、秋季最大, 相关系数 $R>0.75$, 在一定程度上指示了水体的蒸发程度, 与 $\mathrm{TP} 、 \mathrm{Cu}^{2+}$ 、色度、浊度等指标 基本不相关,相关系数 $R<0.25$, 表明氢氧同位素与 $\mathrm{TP}$ 以及一些金属离子和物理指标无明显相关性.

\section{3 结论}

结合野外调研和室内分析等手段,对研究区主要人湖河流博河、精河不同季节水化学特征、污染来源和 氢氧同位素组成进行深人研究,为干旱区湖泊水环境保护及管理提供了科学依据. 主要获得以下结论:

1) 研究区水质指标异常高值多位于城镇以及艾比湖附近，主要受到水体富营养化、工矿业以及有机质 的污染，一般在夏、秋季节水体受到的污染大于春、冬季节.

2) 流域河流水体 $\delta^{18} \mathrm{O}$ 与 $\delta^{2} \mathrm{H}$ 存在明显的线性关系, 各季节相关指数 $R^{2}$ 均大于 0.9 , 且沿当地大气降水 线分布, 受西北干旱区强烈的蒸发作用影响; $d$-excess 值均为正值, 且春季 $(15.4 \% 0)>$ 秋季 $(14.17 \% 0)>$ 夏季 $(13.73 \%)$ ) >冬季 $(12.78 \% 0)$.

$3)$ 博河与精河地表水体 $\delta^{18} \mathrm{O}$ 值整体上表现为沿流程逐渐偏正的趋势, 上游近山区地区, 河水主要来源 
于冰川补给, 而中、下游平坦盆地地区, 河水则主要源于降水补给, 降雨到达地面后在产生地表径流或下渗 的过程中均会遭遇地面蒸发而使其同位素发生变化,故越靠近下游地区氢氧同位素越偏正.

4) 博河水体 $\delta^{18} \mathrm{O}$ 值与海拔高度表现出一定的负相关关系,海拔越高 $\delta^{18} \mathrm{O}$ 越偏轻,且具有季节性变化: 春季 $\left(R^{2}=0.70\right)>$ 冬季 $\left(R^{2}=0.57\right)>$ 夏季 $\left(R^{2}=0.45\right)>$ 秋季 $\left(R^{2}=0.30\right)$; 精河因海拔差异不大, 流程简短,其与 高程相关性低, 夏季 $\left(R^{2}=0.22\right)>$ 春季 $\left(R^{2}=0.20\right)>$ 秋季 $\left(R^{2}=0.11\right)>$ 冬季 $\left(R^{2}=0.001\right)$, 在一定程度上反映了 艾比湖流域降水的高度效应,对流域水循环过程的研究具有重要的水文地质意义.

5 ) 博河和精河氢氧同位素与氯化物、硫酸盐、 $\mathrm{BOD}_{5}$ 等指标间存在相关性, 且在夏、秋季最大 $($ 相关系数 $R>0.75$ ) 在一定程度上指示了水体的蒸发程度, 与 $\mathrm{TP} 、 \mathrm{Cu}^{2+}$ 等金属离子以及色度、浊度等物理指标无明显相 关性 (相关系数 $R<0.25)$.

\section{4 参考文献}

[ 1 ] Kendall C, McDonnell JJ eds. Isotope tracers in catchment hydrology. Amsterdam: Elsevier, 1998: 838.

[ 2 ] Tantawi MA, El-Sayed E, Awad MA. Hydrochemical and stable isotope study of groundwater in Saint Catherine-Wadi Feiran area, South Sinai, Egypt. Journal of African Earth Sciences, 1998, 26(2) : 277-284.

[ 3 ] Dang DN, Lam NV, Long HCH et al. Hydrological characteristics of karstic groundwater in the northeast Viet Nam as studied by isotopic techniques. Environmental Earth Sciences, 2013, 70 (2) : 521-529.

[ 4 ] Al-Gamal SA, Sadek M. An assessment of water resources in Sinai Peninsula, using conventional and isotopic techniques, Egypt. International Journal of Hydrology Science and Technology, 2015, 53(5) : 241-257.

[ 5 ] Ma HY, Yi LH, Zhang J et al. The impact of free air humidity on the fractionation in the process of evaporation. Geological Bulletin of China, 2015, 34(11) : 2087-2091. [马洪云, 尹立河, 张俊等. 蒸发过程中水体稳定同位素富集与空气 湿度的关系. 地质通报, 2015, 34(11): 2087-2091. ]

[ 6 ] Li G, Zhang XP, Zhang LF et al. Stable isotope characteristics in different water bodies in Changsha and implications for the water cycle. Environmental Science, 2015, 36(6) : 2094-2101. [李广, 章新平, 张立峰等. 长沙地区不同水体稳 定同位素特征及其水循环指示意义. 环境科学, 2015, 36(6) : 2094-2101.

[ 7 ] Darling WG, Bowes MJ. A long-term study of stable isotopes as tracers of processes governing water flow and quality in a lowland river basin: the upper Thames, UK. Hydrological Processes, 2016, 30(13) : 2178-2195.

[ 8 ] Freyberg JV, Studer B, Kirchner JW. A lab in the field: high-frequency analysis of water quality and stable isotopes in stream water and precipitation. Hydrology \& Earth System Sciences Discussions, 2017, 21: 1721-1739.

[ 9 ] Mook WG, Tan FC. Stable carbon isotopes in rivers and estuaries. In: Degens ET, Kempe S, Richey JE eds. Biogeochemistry of major world rivers. New York: Wiley, 1991: 245-264.

[10] Zhang J, Letolle R, Martin JM et al. Stable oxygen isotope distribution in the Huanghe (Yellow River) and the Changjiang (Yangtze River ) estuarine systems. Continental Shelf Research, 1990, 10(4) : 369-384.

[11] Ramesh R, Sarin MM. Stable isotope study of the Ganga (Ganges) river system. Journal of Hydrology, 1992, 139( s1-4) : 49-62.

[12] Pawellek F, Frauenstein F, Veizer J. Hydrochemistry and isotope geochemistry of the upper Danube River. Geochimica et Cosmochimica Acta, 2002, 66(21) : 3839-3853.

[13] Karr JD, Showers WJ. Stable oxygen and hydrogen isotopic tracers in Amazon shelf waters duringAmasseds. Oceanologica Acta, 2002, 25(2): 71-78.

[14] Ryu JS, Lee KS, Chang HW. Hydrogeochemical and isotopic investigations of the Han River basin, South Korea. Journal of Hydrology, 2007, 345(1) : 50-60.

[15] Gu WZ, Pang ZH, Wang QJ et al eds. Isotope hydrology. Beijing: Science Press, 2011: 105-238. [ 顾慰祖, 庞忠和, 王 全九等. 同位素水文学. 北京: 科学出版社, 2011: 105-238.]

[16] Yurtsever Y. Worldwide survey of stable isotopes in precipitation. Isotope Hydrology Section report. Vienna: International Atomic Energy Agency, 1975: 1-40.

[17] Shi XY, Pu T, He YQ et al. Spatial distribution of stable isotope from the lakes in typical temperate glacier region. Environmental Science, 2016, 37(5) : 1685-1691. [史晓宜, 蒲春, 何元庆等. 典型温冰川区湖泊的稳定同位素空间分布 特征. 环境科学, 2016, 37(5) : 1685-1691.] 
[18] Gao JF, Ding TP, Luo XR et al. $\delta \mathrm{D}$ and $\delta^{18} \mathrm{O}$ variations of water in the Yellow River and its environmental significance. Acta Geologica Sinica, 2011, 85(4) : 596-602. [高建飞, 丁悌平, 罗续荣等. 黄河水氢、氧同位素组成的空间变化特 征及其环境意义. 地质学报, 2011, 85(4) : 596-602.]

[19] Xu JZ, Xiao W, Xiao QT et al. Temporal dynamics of stable isotopic composition in lake Taihu and controlling factors. Environmental Science, 2016, 37(7):2470-2477. [徐敬争, 肖薇, 肖启涛等. 湖水氢氧同位素组分的时间变化特征及 影响因子分析. 环境科学, 2016, 37(7): 2470-2477.]

[20] Zhang X, Qian H, Chen J et al. Assessment of groundwater chemistry and status in a heavily used semi-arid region with multivariate Statistical analysis. Water, 2014, 6(8): 2212-2232.

[21] Etteieb S, Cherif S, Tarhouni J. Hydrochemical assessment of water quality for irrigation: a case study of the Medijerda River in Tunisia. Applied Water Science, 2017, 7 (1) : 469-480.

[22] Ren Y, Zhang F, Wang J et al. Spatio-temporal characteristics and source identification of surface water pollutants in Lake Ebinur. J Lake Sci , 2017, 29(5) : 1143-1157. DOI: 10.18307/2017.0512. [任岩, 张飞, 王娟等. 新疆艾比湖地域地 表水丰水期和枯水期水质分异特征及污染源解析. 湖泊科学, 2017, 29(5): 1143-1157.]

[23] Kong YL, Pang ZH. Evaluating the sensitivity of glacier rivers to climate change based on hydrograph separation of discharge. Journal of Hydrology, 2012, 434-435(434-435) : 121-129.

[24] Zeng HA, Wu JL. Water isotopic andhydrochemical characteristics and causality in Tajikistan. Advances in Water Science, 2013, 24(2) : 272-279. [曾海鳌, 吴敬禄. 塔吉克斯坦水体同位素和水化学特征及成因. 水科学进展, 2013,24 (2) : 272-279.]

[25] Guo XY. Water chemistry and stable isotope characteristics analysis of different water bodies in the Hutubi River basin [Dissertation]. Urumqi : Xinjiang University, 2016. [ 郭小云. 呼图壁河流域不同水体的水化学和稳定同位素特征分 析[学位论文]. 乌鲁木齐: 新疆大学, 2016. ]

[26] Sheng D, Li JF, Sun FF et al. Study on water-salt change of some inland lakes in arid areas and the control mechanism. Arid Zone Research, 2010, 27(4) : 529-535. [盛东, 李俊峰, 孙飞飞等. 干旱区内陆湖泊水盐变化及调控机理. 干 旱区研究, 2010, 27(4): 529-535. ]

[27] Chen J. Research on water environment and its evolution for lakes in arid region: a case study forShahu lake, Ningxia[Dissertation]. Xi'an: Chang'an University, 2017. [陈洁. 旱区湖泊水环境及其演化研究: 以宁夏沙湖为例 [ 学位论文]. 西安: 长安大学, 2017.]

[28] Bai X. Study on the wetland ecological vulnerability and its driving systemEbinur lake in Xinjiang [ Dissertation]. Shanghai : East China Normal University, 2010. [白祥. 新疆艾比湖湖泊湿地生态脆弱性及其驱动机制研究 [ 学位论 文].上海: 华东师范大学, 2010.]

[29] Li Z, Zhang F, Hsiang-te Kung et al. Spatial and temporal ecosystem changes in the Ebinur wetland nature reserve from 1998 to 2014. Acta Ecologica Sinica, 2017, 15(37) : 4984-4997. [李哲, 张飞, Hsiang-te Kung 等. 1998-2014 年艾 比湖湿地自然保护区生态系统服务价值及其时空变异. 生态学报, 2017, 15(37) : 4984-4997.]

[30] Zhang F, Tiyip T, Johnson VC et al. The influence of natural and human factors in the shrinking of the Ebinur Lake, Xinjiang, China, during the 1972-2013 period. Environmental Monitoring and Assessment, 2015, 187(1) : 1-14.

[31] Ren Y, Zhang F, Zhou M et al. Relationship between water index and chemical characteristics of the surface water: A case study in the Ebinur Lake Basin. Journal of Desert Research, 2016, 36(5) : 1451-1462. [任岩, 张飞, 周梅等. 基于 Landsat 8 影像的水体指数与地表水化学特征关系: 以艾比湖流域为例. 中国沙漠, 2016, 36(5): 1451-1462.]

[32] Xu XB, Wang YH, Yao JQ. Impact of the climate change of Ebinur Lake Basin on surface water resources. Research of Soil and Water Conservation, 2015, 22(3) : 121-126. [许兴斌, 王勇辉, 姚俊强. 艾比湖流域气候变化及对地表水资源 的影响. 水土保持研究, 2015, 22(3): 121-126.]

[33 ] Li BF, Chen YN, Chen ZS. The effect of climate change during snowmelt period on stream flow in the mountainous areas of northwest China. Acta Geographica Sinica, 2012, 67 (11) : 1461-1470. [李宝富, 陈亚宁, 陈忠升. 西北干旱区山区融 雪期气候变化对径流量的影响. 地理学报, 2012, 67(11): 1461-1470. ]

[34] Meng XY, Meng BC, Wang YJ et al. Influence of climate change and human activities on water resources in Ebinur Lake in recent 60 years. Journal of China Hydrology, 2015, 35(2): 90-96. [孟现勇, 孟宝臣, 王月健等. 近 60 年气候变化 及人类活动对艾比湖流域水资源的影响. 水文, 2015, 35(2): 90-96.]

[35] Yuan XC, Zhang LP. Analysis of hydrological characteristics inJinhe River Basin, Xinjiang. Modern Agricultural Science 
and Technology，2010，(6)：290. [袁新春, 张莉萍. 新疆精河流域水文特性分析. 现代农业科技, 2010, (6): 290.]

[36] Zhu YS, Zhang LP. Analysis of hydrology and water resources in theBoltara River Basin. Modern Agricultural Science and Technology, 2010，(7)：295-296. [ 朱永生 张莉萍. 博尔塔拉河流域水文水资源分析. 现代农业科技, 2010，(7)： 295-296. ]

[37] Zhang HW, Zhang F, Li Z et al. Characteristics of three dimensional fluorescence spectra and its correlation with water quality in Jinghe and Bortala River from Lake Ebinur's major inflow tributaries, Xinjiang. J Lake Sci, 2017, 29(5) : 11121120. DOI: $10.18307 / 2017.0509$. [张海威, 张飞, 李哲等. 新疆艾比湖主要人湖河流精河与博尔塔拉河三维菼光 光谱特性及其与水质的关系. 湖泊科学, 2017, 29(5): 1112-1120.]

[38] Zhang B, Song XF, Zhang YH et al. Relationship between surface water and groundwater in the second Songhua River basin. Advances in Water Science, 2014, 25(3) : 336-347. [张兵, 宋献方, 张应华等. 第二松花江流域地表水与地下水 相互关系. 水科学进展, 2014, 25(3): 336-347.]

[39] Gourcy LL, Groening M, Aggarwal PK. Stable oxygen and hydrogen isotopes in precipitation. Isotopes in the water cycle: past, present and future of a developing science. Netherlands: Springer: 2005: 39-51.

[40] Huang JZ, Tan HB, Wang RA et al. Hydrogen and oxygen isotopic analysis of perennial meteoric water in northwest china. Journal of China Hydrology, 2015, 37(5): 33-39. [黄锦忠, 谭红兵, 王若安等. 我国西北地区多年降水的氢氧同位 素分布特征研究. 水文, 2015, 35(1):33-39.]

[41] Xiao K, Shen LC, Wang P. Hydrogen and oxygen isotopes of lake water and geothermal spring water in arid area of South Tibet. Environmental Science, 2014, 35(8): 2952-2958. [肖可, 沈立成, 王鹏. 藏南干旱区湖泊及地热水体氢氧同 位素研究. 环境科学, 2014, 35(8) : 2952-2958.]

[42] Dansgaard W. Stable isotopes in precipitation. Tellus, 1964, 16(4) : 436-468.

[ 43] Yin G, Ni SJ, Zhang QC. Deuterium excess parameter andgeohydrolgy significance-Taking the geohydrology researches in Jiuzaigou and Yele, Sichuan for example. Journal of Chengdu University of Technology, 2001, 28(3) : 251-254. [尹观, 倪师军, 张其春. 氝过量参数及其水文地质学意义: 以四川九寨沟和冶勒水文地质研究为例. 成都理工学院学报, $2001, \mathbf{2 8}(3): 251-254$.

[44] Liu Q. Variations of river water stable isotopes on the TibetanPlaeau and adjacent regions [Dissertation]. Chongqing: Southwest University, 2014. [刘琴. 青藏高原及其周边地区地表水氢氧稳定同位素空间变化特征 [学位论文]. 重 庆: 西南大学, 2014.]

[45] Shi XN, Zhang N, Tian LD et al. Tracing contributions tohydro-isotopic differences between two adjacent lakes in the southern Tibetan Plateau. Hydrological Processes, 2014, 28: 5503-5512.

[46] Wu JL, Liu JJ, Wang S. Climatic change record from stable isotopes in Lake AIBI, Xinjiang during the past 1500 years. Quaternary Research, 2004, 24(5) : 585-590. [ 吴敬禄, 刘建军, 王苏. 近 1500 年来新疆艾比湖同位素记录的气候 环境演化特征. 第四纪研究, 2004, 24(5) : 585-590.]

[47] Gremillion P, Wanielista M. Effects of evaporative enrichment on the stable isotope hydrology of a central Florida (USA) river. Hydrologie Continentale, 2000, 14: 1465-1484.

[ 48] Shi XY, Pu T, He YQ et al. Spatial distribution of stable isotope from the lakes in typical temperate glacier region. Environmental Science, 2016, 37(5) : 1685-1691. [史晓宜, 蒲瑧, 何元庆等. 典型温冰川区湖泊的稳定同位素空间分布 特征. 环境科学, 2016, 37(5): 1685-1691.]

[49] Zhu JJ Chen H, Gong GL. Hydrogen and oxygen isotopic compositions of precipitation and its water vapor sources in EasternQaidam Basin. Environmental Science, 2015, 36(8) : 2784-2790. [ 朱建佳, 陈辉, 巩国丽. 柴达木盆地东部降水氢 氧同位素特征与水汽来源. 环境科学, 2015, 36(8): 2784-2790.]

[50] Deshpande RD, Bhattacharya SK, Jani RA et al. Distribution of oxygen and hydrogen isotopes in shallow groundwaters from Southern India: influence of a dual monsoon system. Journal of Hydrology, 2003, 271(1/2/3/4) : 226-239.

[51] Dotsika E, Lykoudis S, Poutoukis D et al. Spatial distribution of the isotopic composition of precipitation and spring water in Greece. Global \& Planetary Change, 2010, 71(3): 141-149.

[52] Ding L, Xu Q, Zhang LY et al. Regional variation of river water oxygen isotope and empirical elevation prediction models in tibetan plateau. Quaternary Sciences, 2009, 29(1): 1-12. [丁林, 许强, 张利云等. 青藏高原河流氧同位素区域变 化特征与高度预测模型建立. 第四纪研究, 2009, 29(1): 1-12.] 